\title{
Açık Köklü Asma Fidanı Üretiminde Farklı Malç Materyalleri ve Gölgeleme Oranlarının Fidan Randımanı ve Kalitesine Etkileri
}

\section{Adem YAĞCI ${ }^{* 1}$ (D), Muhammet Esat ZENGINOĞLU \\ ${ }^{1}$ Gaziosmanpaşa Üniversitesi, Ziraat Fakültesi, Bahçe Bitkileri Bölümü, 60250 Taşlıçiftlik/TOKAT \\ ${ }^{2}$ Zenginoğlu Fidancılık, Karaoğlanlı/MANiSA}

Öz: Bu çalışmada; arazi koşullarında farklı malç materyalleri (tekstil, beyaz ve siyah Mogul, üstü gri altı siyah malç, siyah plastik malç ve malçsı-kontrol) ve gölgeleme (Kontrol, \%35, ve \%55) oranlarının açık köklü asma fidan randıman ve kalitesine etkisini saptamak amaçlanmıştır. Çalışmada anaç olarak 1613 C ve çeşit olarak Sultani Çekirdeksiz kullanılımıştır. Çalışma sonucunda gölgeleme uygulamalarından sürgün gelişim düzeyi; malç uygulamalarından ise sürgün gelişim düzeyi, sürgün uzunluğu, I ve II. boy fidan randımanı ve toplam randıman etkilenmiştir. En fazla sürgün uzunluğu $(110 \mathrm{~cm})$ ve en fazla toplam fidan randımanı (\%78) \% 35 gölge altında siyah plastik malçtan elde edilmiştir.

Anahtar Kelimeler: bağcılık, Sultani Çekirdeksiz, 1613 C, asma anacı

Effects of Different Mulching Materials and Shading Rates on Sapling Yield and Quality in the Grafted Grapevine Production

Abstract: The aim of the study was to determine of the effects of different mulching treatments (textile mulch, white and black mogul mulch, gray upper side and black lower side plastic mulch, black plastic mulch and mulch-free control) and different shading rates (control, $35 \%, 55 \%)$ on yield and quality of grafted grapevine sapling under field conditions. 1613 C Sultana (seedless grape) grapes were used as the material of study. The results revealed that levels of shoot length were affected from shading applications; and the level of shoot growth, shoot length, first and second size of sapling yield and overall yield were affected from mulching applications. The highest shoot length $(110 \mathrm{~cm})$ and yield $(\% 78)$ were obtained from black plastic mulching application under the shading rate of $35 \%$.

Keywords: viticulture, Sultani seedless, 1613 C, rootstock

\section{GiRiş}

Üreticiler tarafından talep edilen asma fidanları kamu veya özel sektör tarafından karşılanmaya çalışılmaktadır. Fakat kamu veya özel sektör kuruluşlarındaki fidan randımanları \%25-40 arasında değişmektedir (Cangi, 1996; Akman ve Ilgın, 1987). Fidanlıklardaki kayıpların çok yüksek olması fidan üretiminin sayısal olarak azalmasına sebep olmaktadır (Çelik ve Akgül, 1992). Ülkemizin yıllık fidan ihtiyacı kaynaklara göre 7.5 milyon ile 12.5 milyon arasında değişmektedir (Aydın, 2012). Türkiye'de beş yıllık ortalamaya göre (2012-2016 yılları) yıllık 5.054.046 adet asma fidanı üretilmiştir (Çelik, 2017). Çeşit düzeyinde ise en fazla üretilen asma fidanı Sultani Çekirdeksiz üzüm çeşidine aittir (Çelik, 2012).

Asma fidanı üretiminde randıman düşüklüğünün nedenleri arasında, kullanılan materyallerden (bitkisel veya diğerleri, parafin, aşı makinesi vb) uygulanan fidan üretim tekniklerine kadar birçok faktör etki edebilmektedir. Asma fidan üretimi çeşitli bölümlerden meydana gelmiş bir sistem olarak düşünülürse, fidan ile ilgili yapılan çalışmalar, doğal olarak sistemin bir parçası üzerinde olmaktadır. Bu nedenle araştırıcılar fidan üretimi ile ilgili belirli aşamalar üzerinde çalışmalarını yürütmüştür.

Malçlama; toprak yüzeyinin organik ve inorganik maddelerle kaplanması işlemine denir (Sevgican, 1999). Malçlamada kullanılan materyal çeşidine, süresine, uygulama şekline göre değişmekle beraber yapılan çalışmalarda malçlamanın faydaları aşağıdaki gibi sıralanmıştır. Bunlar;

Verim artışı, erkenciliğin ya da geçciliğin sağlaması, topraktan su kaybının önlenmesi, yabancı ot kontrolünün sağlanması, toprak yapısının iyileştirilmesi, toprak erozyonunun önlemesi ve topraktaki mikroorganizma faaliyetlerinin artırılmasıdır (Libik ve Wojtaszek, 1973; Abak ve ark., 1991; Geboloğlu, 1998; Kitiş, 2002; Karipçin, 2004; Lopez-Pineiro ve ark., 2008)

Yapılan birçok çalışmada fidan yetiştiriciliğinde malç kullanımının toprak nemini muhafaza ettiği, yabancı ot kontrolü sağladığı, toprak sıcaklığını artırdığı ve böylelikle kök büyümesini teşvik ederek fidan kalite ve randımanını da artırdığı bildirilmektedir (Ağaoğlu, 1977; Yazgan, 1987; Çelik ve Odabaş, 1996).

Son yıllarda, ürünleri güneşin yakıcı etkisinden ve dolu zararından korumak için gölgeleme materyallerinden yararlanılmaktadır. Değişik yoğunlukta gölgeleme oranına sahip olan file veya ağ denilen örtüler asma fidanı yetiştiriciliğinde ve bağlarda kullanım alanı bulmuştur. Bağlarda gölgeleme uygulamaları, dünyanın değişik

Sorumlu Yazar: adem.yagci@gop.edu.tr Bu çalışma yüksek lisans tez ürünüdür ve 09-12 Mayıs 2018'de Van'da düzenlenen Uluslararası Tarım Kongresinde sunulmuş ve özeti kongre kitabında basılmıştır. Geliş Tarihi: 3 Temmuz 2019

Kabul Tarihi: 21 Aralık 2019 
bölgelerinde pratik olarak uygulanmaya başlamış olup (Kliewer ve ark., 1967; Smart ve ark., 1988; Keller ve ark., 1998; Yağcı ve Aydin, 2015; Yağcı ve Gökkaynak, 2016) konu üzerinde araştırmalar yapılmaya devam etmektedir

$\mathrm{Bu}$ çalışmada; farklı gölge oranları altında, farklı malç materyallerinin (tekstil malç, beyaz mogul, siyah mogul, üstü gri altı siyah malç, siyah malç ve malçsız-kontrol) açık köklü asma fidan üretiminde randıman ve kalite parametrelerini; ayrıca farklı malç materyallerinin toprak ve bitki üzerindeki sıcaklık yönünden etkilerini de belirlemek amaçlanmıştır.

\section{MATERYAL VE YÖNTEM}

\section{Materyal}

Manisa ili Turgutlu ilçesinde yapılan bu çalışmada bitkisel materyal olarak Sultani Çekirdeksiz üzüm çeşidi (K- 7 klonu) ile $1613 \mathrm{C}$ anacı (Şekil 1) kullanılmıştır. Gölgeleme için \%0 (kontrol), \%35 ve \%55 gölge oranına sahip netler (Şekil 2); malç materyali olarak ise tekstil malç, beyaz mogul, siyah mogul, üstü gri altı siyah plastik malç, siyah plastik malç (Şekil 3) ve malçsız (kontrol) uygulamalar yer almıştır. Tekstil malç polipropilenden imal edilmiştir. Gözenekli bir yapıya sahiptir. Hava ve suyun giriş çıkışına izin vermektedir. Beyaz mogul (Agrimol) ve siyah mogul polipropilenden imal edilmiştir. UV katkıları \%3'tür ve ışık geçirgenliği \%70'dir. (Kesgin, 2011). Üstü gri altı siyah plastik malç ile siyah renkli malç; $120 \mathrm{~cm}$ genişliğinde, $0.50 \mathrm{~mm}$ kalınlığında ve polietilen malzemeden üretilmişlerdir. Örtü üzerinde su ve hava geçişi olmamaktadır.

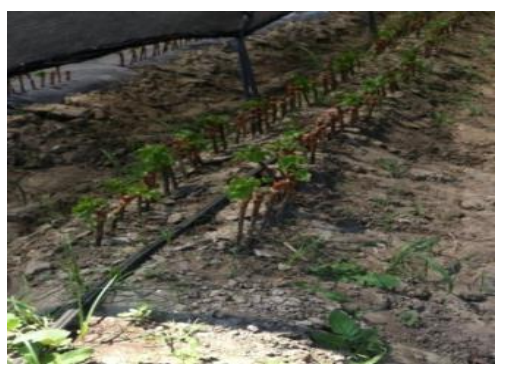

Kontrol (malçsız)

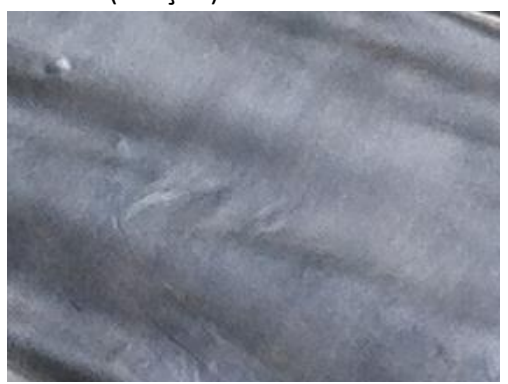

Üstü gri altı siyah malç

Şekil 3. Çalışmada kullanılan malç materyalleri

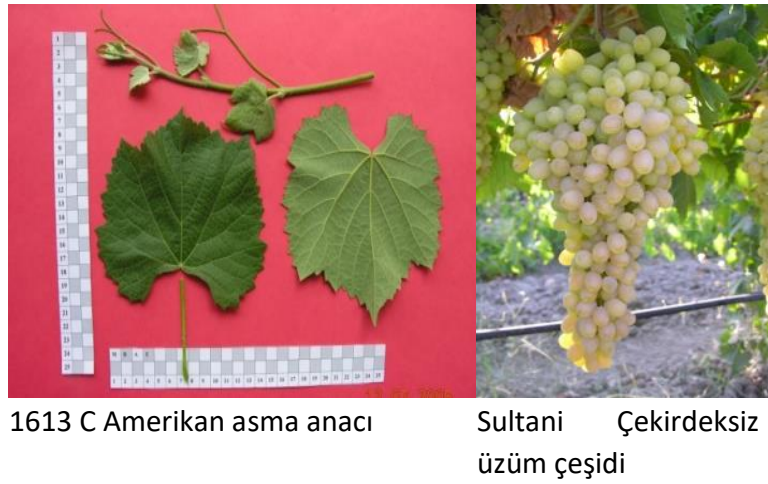

Şekil 1. Çalışmada kullanılan bitkisel materyal

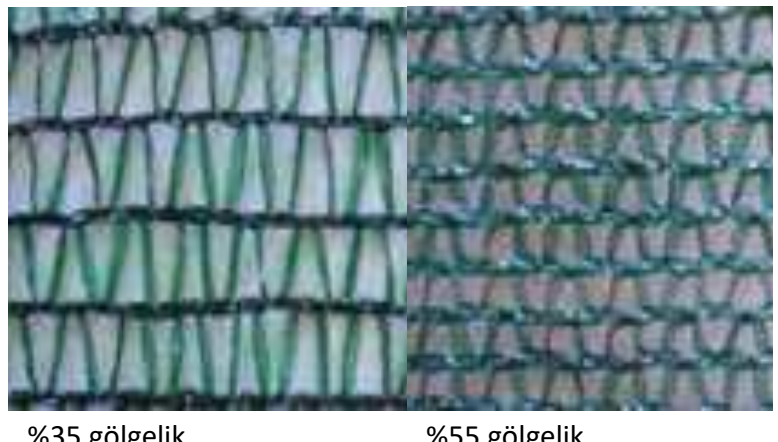

Şekil 2. Çalışmada kullanılan gölge materyalleri

\section{Yöntem}

Aşılamada kullanılacak bitkisel materyaller aşılama zamanına kadar \%80-95 nem ve 0-4 ${ }^{\circ} \mathrm{C}$ ' deki soğuk hava deposunda muhafaza edilmiştir (Ağaoğlu ve Çelik, 1978).

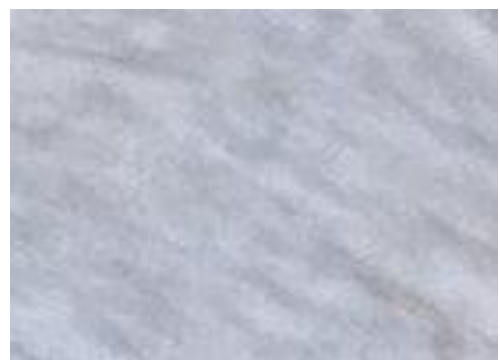

Beyaz mogul

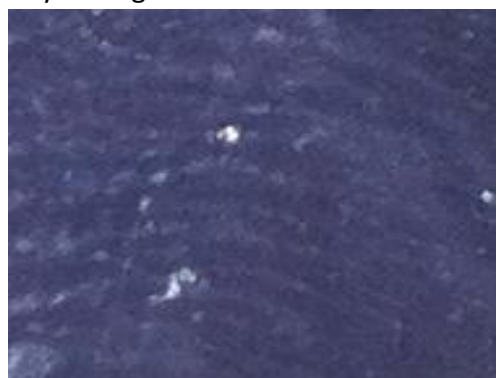

Siyah plastik malç

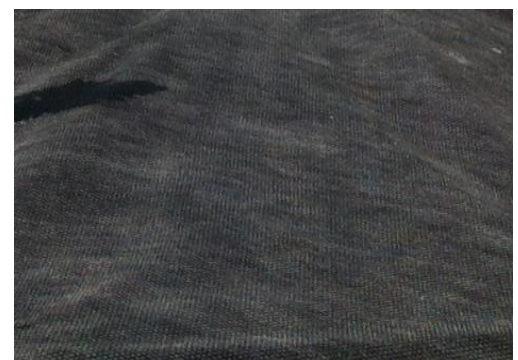

Siyah mogul

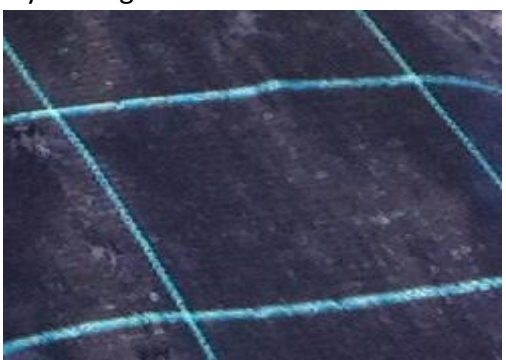

Tekstil malç 
Daha sonra parafinleme, katlama ve kaynaştırma işlemi yapılmıştır. Kaynaştırma odası koşulları Çelik (1982), Akman ve Ilgın (1987)'na göre düzenlenmiştir (3 gün 28-29 ${ }^{\circ} \mathrm{C}, 15$ gün $25-26^{\circ} \mathrm{C}$ ve 3 gün $22-24{ }^{\circ} \mathrm{C}$; nem oranı $\% 85-95$; 6-12 Aşı öncesi anaca ait çelikler 2 gün, çeşide ait kalemler ise 1 gün su içinde bekletilmiştir. Aşılama işlemi omega şeklinde kesit açan makinelerde 25 Mart 2013 tarihinde yapılmıştır. saatte bir havalandırma). İkinci parafinleme sonrası ve dikim öncesi aşılı materyalin dip kısımları 2000 ppm'lik IBA (Indole-3-butyric acid) ile muamele (Sağlam ve ark., 2005) edilmiştir.

Arazide toprak önce dip kazanla işlenmiş sonra kulaklı pullukla iki sefer sürülmüştür. Diskaro ile arazide var olan kesekler parçalanmış ve masura aleti ile masuralar oluşturulmuştur. Masuralar arası $100 \mathrm{~cm}$ dir. Her masuraya $33 \mathrm{~cm}$ de bir damlatıcısı olan damla lateral borular serilmiş ve masura yüzeyine kullanılan malç materyalleri serilmiştir. Aşılı materyaller çift sıralı olacak şekilde $8 \times 24 \mathrm{~cm}$ sıklıkta dikilmiştir.

Fidan dikimleri 25 Nisan 2013 tarihinde yapılmış olup söküme kadar bakım işleri (sulama, gübreleme, hastalık, zararlı ve yabancı ot mücadelesi) düzenli olarak yapılmıştır. Gölge materyalleri 5 Ağustos 2013 tarihinde fidanların üzerinden kaldırılmış ve fidan sökümü 17 Aralık 2013 tarihinde gerçekleştirilmiştir.

Fidanlarda; randıman (Eşitlik 1), kök sayısı (adet) ve sürgün uzunluğu değerlerine bakılmıştır (Uzun, 2019).

Randıman $(\%)=\frac{\text { Sökülen fidan sayısı }}{\text { Dikilen çelik sayısı }} \times 100$

(Eşitlik 1)

Aşı noktasında bulunan parafin sıcaklığı, örtü materyalinin yüzey sıcaklığı ve toprağın yüzeyden $15 \mathrm{~cm}$ altındaki sıcaklıklar günün belli saatlerinde (07:00-14:00 ve 21:00) laser ve toprak termometre ile dikimden itibaren 30 gün süre boyunca her gün ölçülmüştür.

Deneme planı ve istatistiksel analiz

Tesadüf bloklarında bölünmüş parseller deneme desenine göre kurulmuş olan araştırmada 1613 C Amerikan asma anacı üzerine Sultani Çekirdeksiz çeşidi aşılanmıştır. Çalışma, 6 farklı malç uygulaması [Tekstil malç, Beyaz Mogul, Siyah Mogul, Üstü gri altı siyah malç, Siyah plastik malç, Malçsız (kontrol)], ve 3 farklı gölge oranına sahip netler (\%35 gölgelik, \%55 gölgelik, açık-kontrol) ile birlikte kurulmuş 18 farklı uygulamadan oluşmaktadır. Çalışma 3 tekerrürlü ve her tekerrürde 100 adet aşılı çelik yer alacak şekilde planlanmıştır. Elde edilen veriler varyans analizine tabi tutulduktan sonra ortalamaların karşılaştırılmasında LSD $_{(0.05)}$ testi uygulanmıştır.

Yüzde değişim: Yüzde değişim, elde edilen verilerin kontrole göre pozitif veya negatif yönde değişim oranını ortaya koyan önemli bir göstergedir. Çalışmada yüzde değişim aşağıdaki formüle göre hesaplanmıştır (Eşitlik 2).

$$
Y \text { üzde Değișim }=\left(\frac{\text { Kontrol }}{\text { Uygulama }}-1\right) \times 100
$$

BULGULAR ve TARTIŞMA

\section{Uygulamalarının toprak, örtü ve aşı bölgesi sıcaklık} değerlerine etkisi

2013 yılında yapılan çalışmada farklı malç uygulamalarına ait toprak, örtü yüzeyi ve kallus dokusuna ait sıcaklık değerleri 05 Mayıs - 6 Haziran arasında 30 gün süre ile ölçülmüştür. Ortalama sıcaklık değerleri Çizelge $1^{\prime}$ de verilmiştir.

Toprağın $15 \mathrm{~cm}$ altında ölçülen en yüksek sıcaklık ortalaması saat $21: 00^{\prime}$ de açıkta üst gri alt siyah malçta $\left(28.0^{\circ} \mathrm{C}\right)$, en düşük sıcaklık ise saat 07:00'de \%55 gölge altında malçsız masuralarda $\left(17.5{ }^{\circ} \mathrm{C}\right)$ meydana gelmiştir. En fazla örtü yüzey sıcaklığı saat 14:00'de açıkta bulunan siyah malçda ölçülürken $\left(48.1{ }^{\circ} \mathrm{C}\right)$, en düşük sıcaklık ise saat 21:00'de açıkda bulunan beyaz mogulda $\left(13.2^{\circ} \mathrm{C}\right)$ ölçülmüştür. Aşı noktası sıcaklığı en fazla saat 14:00'de açıkta bulunan tekstil malçta $\left(40.8^{\circ} \mathrm{C}\right)$ ölçülürken, en düşük sıcaklık ise saat 21:00'de açıkta bulunan siyah mogulda $\left(17.5{ }^{\circ} \mathrm{C}\right)$ ölçülmüştür (Çizelge 1)

Kullanılan malç materyallerinin farklı gölge oranlarına sahip örtüler altındaki toprağın $15 \mathrm{~cm}$ altındaki sıcaklığı, örtü yüzey sıcaklığı ve aşı noktası sıcaklıkları Şekil 4, 5 ve 6’da verilmiştir.

En yüksek sıcaklık ölçümleri açıkta yapılan yetiştiricilikte, en düşük sıcaklık ölçümleri ise $\% 55$ gölge altında yapılan yetiştiricilikte ölçülmüştür. Açıkta kullanılan malç materyallerinden üstü gri altı siyah plastik malç toprak sıcaklığı $\left(26.3^{\circ} \mathrm{C}\right)$; siyah plastik malç, örtü yüzey sıcaklığı $\left(31.0{ }^{\circ} \mathrm{C}\right)$; tekstil malç ise aşı noktası sıcaklığı $\left(26.8{ }^{\circ} \mathrm{C}\right)$ bakımından ön plana çıkmıştır. Bununla birlikte \%55 gölge altında en düşük toprak sıcaklığı $\left(18.7^{\circ} \mathrm{C}\right)$, en düşük yüzey sıcaklığı $\left(20.3^{\circ} \mathrm{C}\right)$ ve en düşük aşı noktası sıcaklığı $\left(21.8^{\circ} \mathrm{C}\right)$ kontrol (açıkta) uygulamasında belirlenmiştir. Gölge uygulamasından en fazla etkilenen malç materyalleri Siyah plastik ve kontrol uygulamaları olmuştur. Şöyle ki; açıkta siyah plastik malç $31.0{ }^{\circ} \mathrm{C}$ iken $\% 55$ gölgede $7{ }^{\circ} \mathrm{C}$ düşerek $24.0^{\circ} \mathrm{C}^{\prime}$ ye inmiştir. Gölge uygulamalarından en az etkilenen malç materyali ise beyaz mogul örtüsü olmuştur. Bu örtü tipinde açıkta, \%35 ve \%55 gölgede ölçülen değerler hemen hemen aynı olmuştur $\left(20.5^{\circ} \mathrm{C}\right.$ ) (Şekil 4, 5 ve 6).

Elde edilen sonuçlar, koyu renkli materyallerin solar radyasyonu daha fazla absorbe ettiğini ve radyasyon ile topraktan ısı kaybını önleyerek toprak sıcaklığını artırdığını bildiren Abak ve ark., (1991), Küçükyumuk (2009) gibi araştırmacıların sonuçları ile benzerlik göstermektedir.

Kesgin (2011) üzümlerde hasadı geciktirmek için Temmuz ayında yapılan gölgeleme çalışmasında; günün aydınlık olduğu zamanlarda gölge oranı arttıkça gölge altındaki sıcaklığında arttığını, Aydin (2012) ise fidan üretiminde farklı gölge materyalleri ile yapmış olduğu çalışmada sıcaklık değerlerinin gölge oranı arttıkça azaldığını bildirmektedir. Bu çalışmada sonucu elde edilen bulgular Aydin (2012) ile benzer bulunmuştur. Fakat Kesgin (2011) ile ortaya çıkan farklılık gölgelemenin farklı zamanlarda yapılmasına ve gölge altına alınan bitkilerin farklı gelişme periyotlarında olmasına bağlı olduğu düşünülmektedir. 
Çizelge 1. Gölge oranlarına göre toprak, örtü ve aşı bölgesi sıcaklıkları $\left({ }^{\circ} \mathrm{C}\right)$

\begin{tabular}{|c|c|c|c|c|c|c|c|c|c|}
\hline Ölçüm yeri & Saat & $\begin{array}{l}\text { Gölgeleme } \\
(\%)\end{array}$ & Oranı & $\begin{array}{l}\text { Tekstil } \\
\text { malç }\end{array}$ & $\begin{array}{l}\text { Beyaz } \\
\text { Mogul }\end{array}$ & $\begin{array}{l}\text { Siyah } \\
\text { Mogul }\end{array}$ & $\begin{array}{l}\text { Üst gri alt } \\
\text { siyah }\end{array}$ & Açıkta & $\begin{array}{l}\text { Siyah } \\
\text { Plastik }\end{array}$ \\
\hline \multirow{9}{*}{$\begin{array}{l}\text { Toprak Alt } \\
\text { sıcaklığı }\end{array}$} & \multirow{3}{*}{ 07:00 } & \%35 gölge & & 21.4 & 20.8 & 20.1 & 21.5 & 19.1 & 21.8 \\
\hline & & \%55 gölge & & 19.5 & 19.3 & 18.7 & 18.9 & 17.5 & 20.4 \\
\hline & & Açık & & 23.4 & 23.5 & 23.3 & 24.1 & 21.9 & 23.7 \\
\hline & \multirow{3}{*}{$14: 00$} & \%35 gölge & & 23.1 & 23.0 & 21.9 & 23.8 & 21.2 & 22.8 \\
\hline & & \%55 gölge & & 20.9 & 20.5 & 19.8 & 20.3 & 18.8 & 21.7 \\
\hline & & Açık & & 26.6 & 27.0 & 26.1 & 27.0 & 25.7 & 26.5 \\
\hline & \multirow{3}{*}{ 21:00 } & \%35 gölge & & 24.1 & 23.4 & 22.4 & 24.6 & 22.0 & 24.2 \\
\hline & & \%55 gölge & & 22.1 & 21.7 & 20.5 & 21.0 & 19.9 & 22.2 \\
\hline & & Açık & & 27.4 & 27.5 & 27.0 & 28.0 & 26.3 & 27.1 \\
\hline \multirow{9}{*}{$\begin{array}{l}\text { Örtü yüzey } \\
\text { sıcaklığı }\end{array}$} & \multirow{3}{*}{ 07:00 } & \%35 gölge & & 18.7 & 16.2 & 17.6 & 18.7 & 18.1 & 19.8 \\
\hline & & \%55 gölge & & 18.8 & 17.4 & 18.4 & 19.0 & 17.4 & 19.6 \\
\hline & & Açık & & 22.9 & 16.7 & 21.2 & 23.6 & 20.2 & 24.5 \\
\hline & \multirow{3}{*}{$14: 00$} & \%35 gölge & & 36.9 & 29.2 & 35.1 & 38.6 & 32.0 & 40.7 \\
\hline & & \%55 gölge & & 29.7 & 26.2 & 29.0 & 33.1 & 25.9 & 32.0 \\
\hline & & Açık & & 46.4 & 31.5 & 42.4 & 43.2 & 41.9 & 48.1 \\
\hline & \multirow{3}{*}{$21: 00$} & \%35 gölge & & 18.2 & 16.5 & 18.0 & 19.1 & 17.8 & 20.5 \\
\hline & & \%55 gölge & & 18.9 & 17.6 & 17.9 & 19.1 & 17.7 & 20.5 \\
\hline & & Açık & & 18.9 & 13.2 & 17.3 & 17.9 & 19.9 & 20.4 \\
\hline \multirow{9}{*}{$\begin{array}{l}\text { Aşı noktası } \\
\text { sıcaklığı }\end{array}$} & \multirow{3}{*}{ 07:00 } & \%35 gölge & & 19.4 & 18.3 & 18.5 & 18.1 & 18.3 & 19.1 \\
\hline & & \%55 gölge & & 19.4 & 18.7 & 18.2 & 18.3 & 17.6 & 18.1 \\
\hline & & Açık & & 21.3 & 20.4 & 20.3 & 21.1 & 20.9 & 20.0 \\
\hline & \multirow{3}{*}{$14: 00$} & \%35 gölge & & 35.7 & 31.0 & 34.1 & 33.2 & 32.4 & 35.3 \\
\hline & & \%55 gölge & & 32.5 & 29.4 & 29.2 & 29.9 & 29.1 & 30.7 \\
\hline & & Açık & & 40.8 & 36.9 & 38.4 & 38.7 & 38.8 & 38.4 \\
\hline & \multirow{3}{*}{$21: 00$} & \%35 gölge & & 18.5 & 17.8 & 18.3 & 18.5 & 18.3 & 19.0 \\
\hline & & \%55 gölge & & 19.9 & 18.9 & 18.8 & 18.9 & 18.9 & 19.8 \\
\hline & & Açık & & 18.5 & 18.1 & 17.5 & 18.5 & 18.7 & 19.1 \\
\hline
\end{tabular}

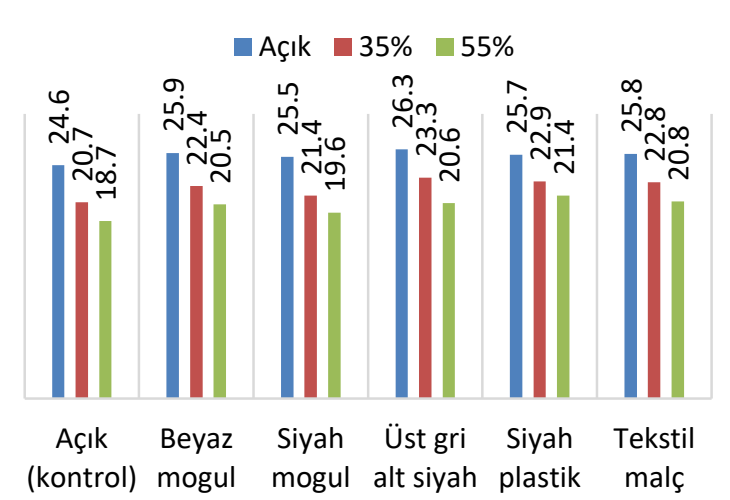

Şekil 4. Farklı gölge ve malç tipine göre toprak sıcaklığı $\left({ }^{\circ} \mathrm{C}\right)$

\section{Uygulamaların fidan randıman ve kalitesi üzerine etkileri}

Çalışmada yer alan farklı malç ve gölgeleme oranlarının Sultani Çekirdeksiz üzüm çeşidinde toplam randımana olan etkileri Çizelge 2 ve Şekil 7'de verilmiştir. Toplam fidan randımanı malç tipi bakımından anlamlı bulunurken, gölge oranı ve interaksiyon önemsiz bulunmuştur. En yüksek randıman \%55 gölgelik altındaki siyah plastik malç (\%77.0)

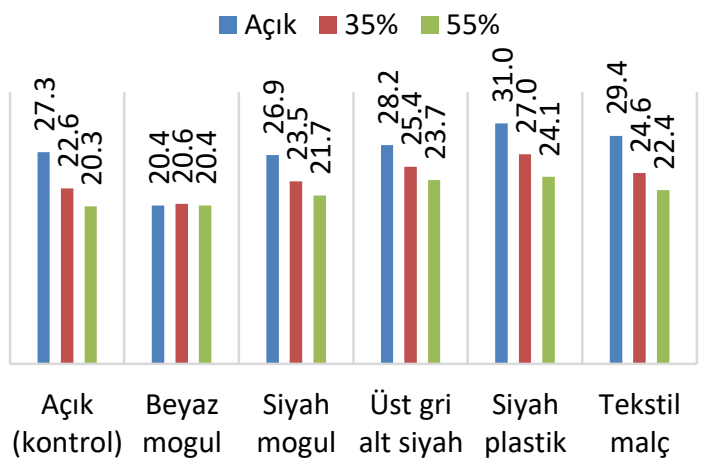

Şekil 5. Farklı gölge ve malç tipine göre örtü yüzey noktası sıcaklığı $\left({ }^{\circ} \mathrm{C}\right)$

uygulamasından, en düşük randımanı ise açıkta üstü gri altı siyah malç (\%56.7) uygulamasından elde edilmiştir. Malç uygulamaları arasında en yüksek fidan randımanı siyah plastik malç (\%77.4), en düşük randıman üstü gri altı siyah malç (\%62.6) uygulamasından alınmıştır. Gölgeleme uygulamaları arasından çok büyük farklılık bulunmamaktadır. En yüksek randıman \%55 gölge 


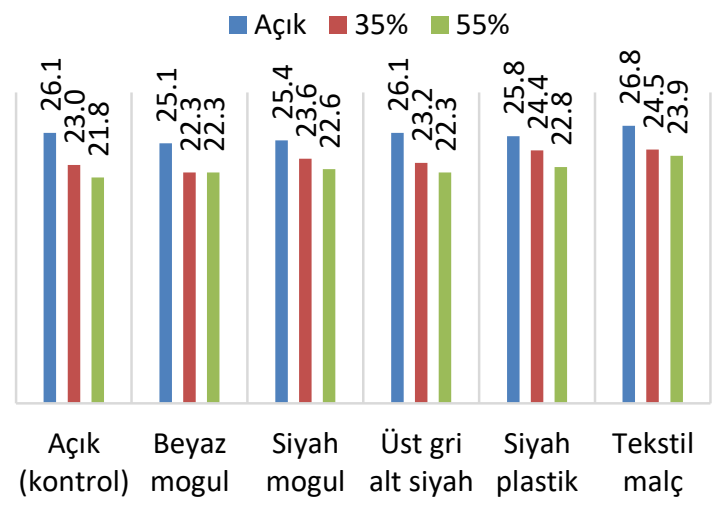

Şekil 6. Farklı gölge ve malç tipine göre aşı noktası sıcaklık değeri $\left({ }^{\circ} \mathrm{C}\right)$

Çizelge 2. Uygulamaların fidan randımanı üzerine etkileri (\%)

\begin{tabular}{lllll}
\hline & Açıkta & \%35 gölge & \%55 gölge & Malç Ortalaması \\
\hline Beyaz Mogul & 63.3 & 63.3 & 68.7 & $65.1 \mathrm{~cd}$ \\
Kontrol & 74.7 & 72.0 & 75.0 & $73.8 \mathrm{ab}$ \\
Siyah Mogul & 68.0 & 71.7 & 69.7 & $69.8 \mathrm{bc}$ \\
Siyah Plastik Malç & 77.3 & 78.0 & 77.0 & $77.4 \mathrm{a}$ \\
Tekstil Malç & 76.3 & 66.3 & 72.7 & $71.8 \mathrm{ab}$ \\
Üst gri alt siyah & 56.7 & 66.7 & 64.3 & $62.6 \mathrm{~d}$ \\
\hline Gölge Ortalaması & 69.4 & 69.7 & 71.2 & \\
\hline
\end{tabular}

Gölge LSD $_{(0,05)}$ : -Ö.D; Malç LSD $(0,05)$ : - 6,5; Gölge x Malç LSD $(0,05)$ : -Ö.D;

Harf bulunmayan parametrelerde istatistiki olarak fark yoktur.

\begin{tabular}{|r|r|r|r|r|}
\hline & 10 \\
\hline & 5 & & \\
\hline
\end{tabular}

Şekil 7. Toplam fidan randımanında yüzde etki

Fidan yetiştiriciliğinde gölge uygulamasının olumlu etkileri, yapılan çalışmalarla belirlenmiştir. Araştırıcılar en yüksek fidan randımanı \%55 gölge uygulamasında (Yağcı ve ark., 2012; Yağcı ve Aydın, 2015; Yağcı ve Gökkaynak, 2016) elde etmişlerdir. Fidan üretiminde kullanılan malç tipinin önemli olduğu; fakat bu durumun anaçlara ve yıllara göre değişebileceği bildirilmektedir. Örneğin iki yıl süre ile yapılan bir çalışmada; en yüksek fidan randımanı I. yıl 5 BBçim uygulaması (\%87.56), II. yıl 140 Ruggeri-plastik malç uygulaması (\%94.67)'dan elde edilmiştir (Küçükyumuk, 2009). Bu çalışmadan belirlenen fidan randıman değerleri önceki araştırma sonuçları ile paralellik göstermektedir. (\%71.2)uygulamasından elde edilirken bunu sırasıyla \%35 gölge (\%69.7) ve açık (\%69.4) uygulaması izlemiştir (Çizelge 2).

Yüzde değişimi belirlemek için kontrol (malçsız) uygulamasından elde edilen veriler dayanak noktası olarak kabul edildiğinde uygulamaların yüzdesel değişimi Şekil 7'de gösterilmiştir. Siyah plastik malç uygulaması ile tekstil malcın uygulamasının açık alandaki yetiştiriciliği hariç diğer malç uygulamalarının hepsi kontrol uygulamasına göre fidan randımanından olumsuz yönde etkilenmiştir. Siyah plastik malç kullanımı açık alanda \%4, \%35 gölgeleme altında $\% 8$ ve $\% 55$ gölge altında $\% 3$ oranında randıman artışına neden olmuştur. Uygulamalar içerisinde kontrole göre en düşük ve en fazla sapma açıkta, üstü gri altı siyah malç (\%24 azalış) uygulamasından elde edilmiştir (Şekil 7). 
Çizelge 3. Uygulamalarının kök sayısı üzerine etkileri (adet)

\begin{tabular}{lllll}
\hline & Açıkta & \%35 gölge & \%55 gölge & Malç Ortalaması \\
\hline Beyaz Mogul & 12.4 & 10.5 & 13.2 & 12.0 \\
Kontrol & 11.2 & 10.4 & 10.7 & 10.7 \\
Siyah Mogul & 11.4 & 11.6 & 11.9 & 11.6 \\
Siyah Plastik & 12.7 & 12.7 & 11.3 & 12.2 \\
Tekstil Malç & 11.9 & 10.7 & 11.9 & 11.5 \\
Üst gri alt siyah & 12.6 & 12.5 & 11.2 & 12.1 \\
\hline Gölge Ortalaması* & 12.0 & 11.4 & 11.7 & \\
\hline
\end{tabular}

Gölge LSD $_{(0,05)}$ : -Ö.D; Malç LSD $(0,05)$ : - Ö.D; Gölge x Malç LSD $(0,05)$ : -Ö.D

Kök gelişimine ait yüzdesel etki Şekil 8'de gösterilmiştir. \%55 gölgeleme koşullarında beyaz mogul kullanımı, kök sayısını \%23 oranında arttırdığı ve bu materyalin diğer uygulamalar arasında da en iyi etkiye sahip olduğu saptanmıştır. Diğer yandan \%35 gölgeleme koşullarında siyah plastik materyalinde \%22 olumlu etkiye sahip olduğu tespit edilmiştir. Elde edilen verilere göre tüm uygulamalar; bütün gölgeleme şartları altında değişik oranlarda etki göstermiş olup tüm uygulamalar pozitif bir etkiye sahip olmuştur.

Asma fidanı üretiminde yapılan çalışmalarda kök gelişim değerleri; kullanılan Amerikan asma anacına, çeşitlere, sulama aralıklarına, malç tipine, hormon seviyesine ve köklenme ortamına göre farklılıklar gösterebilmektedir (Şen ve Yağcı, 2016). Yapılan bu çalışmada gölge ve malç uygulamalarının kök gelişim düzeyi bakımından etkilenmediği her uygulamanın yeterli sayıda kök gelişimi sağladığı görülmüştür.
Uygulamaların sürgün uzunluğu üzerine etkisi

Farklı malç ve gölgeleme oranlarının Sultani Çekirdeksiz üzüm çeşidinde sürgün uzunluğuna olan etkileri Çizelge 4 ve Şekil 9'da verilmiştir. Sürgün uzunluğu değerleri malç tipi ve malç tipi $x$ gölge oranı interaksiyonu bakımdan anlamlı derecede önemli bulunmuştur. En fazla sürgün uzunluğu siyah plastik malç ve $\% 35$ gölge uygulamasından $(110.7 \mathrm{~cm})$ elde edilirken en kısa sürgün uzunluğu ise açıkta malçsız yetiştiricilikte $(50.6 \mathrm{~cm})$ ölçülmüştür. Gölge oranı bakımından anlamlı bir farklılığa rastlanmamıştır. Malç materyalleri bakımından en yüksek değer üstü gri altı siyah uygulamasından $(96.4 \mathrm{~cm})$ elde edilmiş ve bunu siyah plastik malç $(93.8 \mathrm{~cm})$ uygulaması izlemiştir.

Malç ve gölge uygulamalarının sürgün uzunluğuna olan yüzdesel etkisi Şekil 9'da gösterilmiştir. \%35 gölge altında yetiştirilen tekstil malç (\%-17) ile beyaz mogul (\%-21) hariç olmak üzere bütün uygulamalar kontrole göre sürgün uzunluğunu artırmıştır. En fazla artış açıkta üstü gri altı siyah

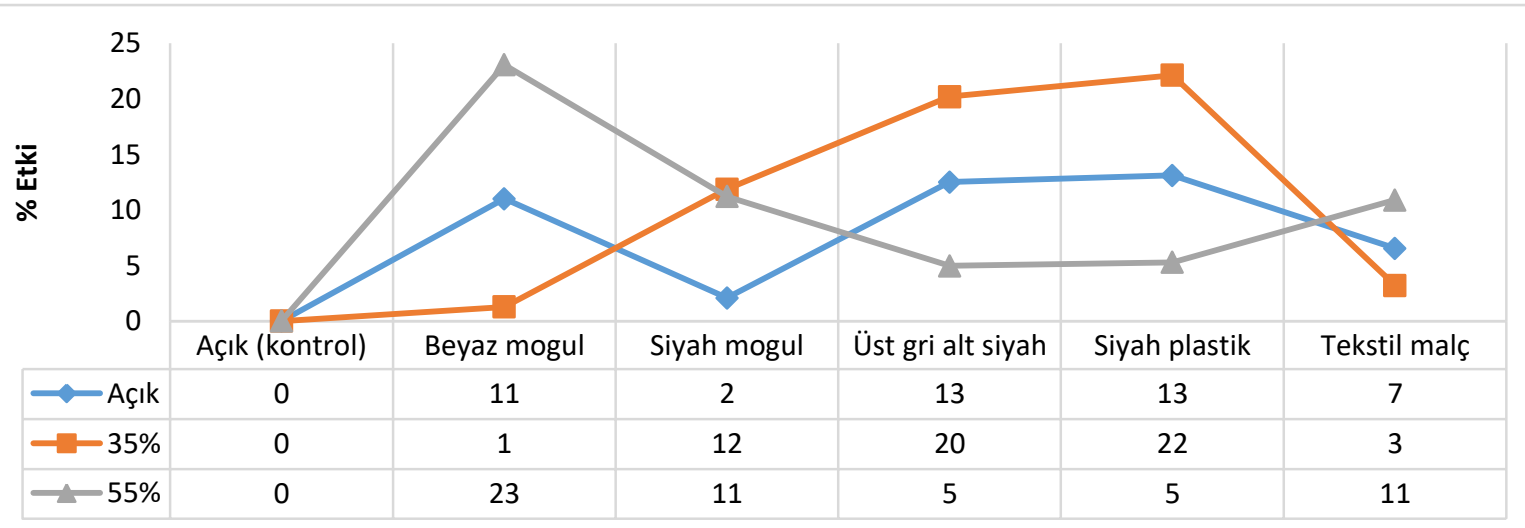

Şekil 8. Kök sayısında yüzde etki

Çizelge 4. Uygulamaların sürgün uzunluğu üzerine etkileri $(\mathrm{cm})$

\begin{tabular}{lllll}
\hline & Açıkta & \%35 gölge & \%55 gölge & Malç Ortalaması \\
\hline Beyaz Mogul & $68.3 \mathrm{cde}$ & $62.7 \mathrm{de}$ & $106.4 \mathrm{ab}$ & $79.1 \mathrm{abc}$ \\
Kontrol & $50.6 \mathrm{e}$ & $79.1 \mathrm{abcde}$ & $61.1 \mathrm{de}$ & $63.6 \mathrm{c}$ \\
Siyah Mogul & $62.5 \mathrm{~cd}$ & $96.3 \mathrm{abc}$ & $70.0 \mathrm{cde}$ & $76.3 \mathrm{bc}$ \\
Siyah Plastik malç & $92.4 \mathrm{abcd}$ & $110.7 \mathrm{a}$ & $78.3 \mathrm{bcde}$ & $93.8 \mathrm{ab}$ \\
Tekstil Malç & $71.3 \mathrm{cde}$ & $65.5 \mathrm{cde}$ & $90.7 \mathrm{abcd}$ & $75.8 \mathrm{bc}$ \\
Üst gri alt siyah & $105.8 \mathrm{ab}$ & $104.9 \mathrm{ab}$ & $78.4 \mathrm{bcde}$ & $96.4 \mathrm{a}$ \\
\hline Gölge Ortalaması* & 75,1 & 86,5 & 80,8 & \\
\hline
\end{tabular}

Gölge LSD $_{(0,05)}$ : Ö.D; Malç LSD $(0,05): 18,5 ;$ Gölge x Malç LSD ${ }_{(0,05)}: 32,1$ 


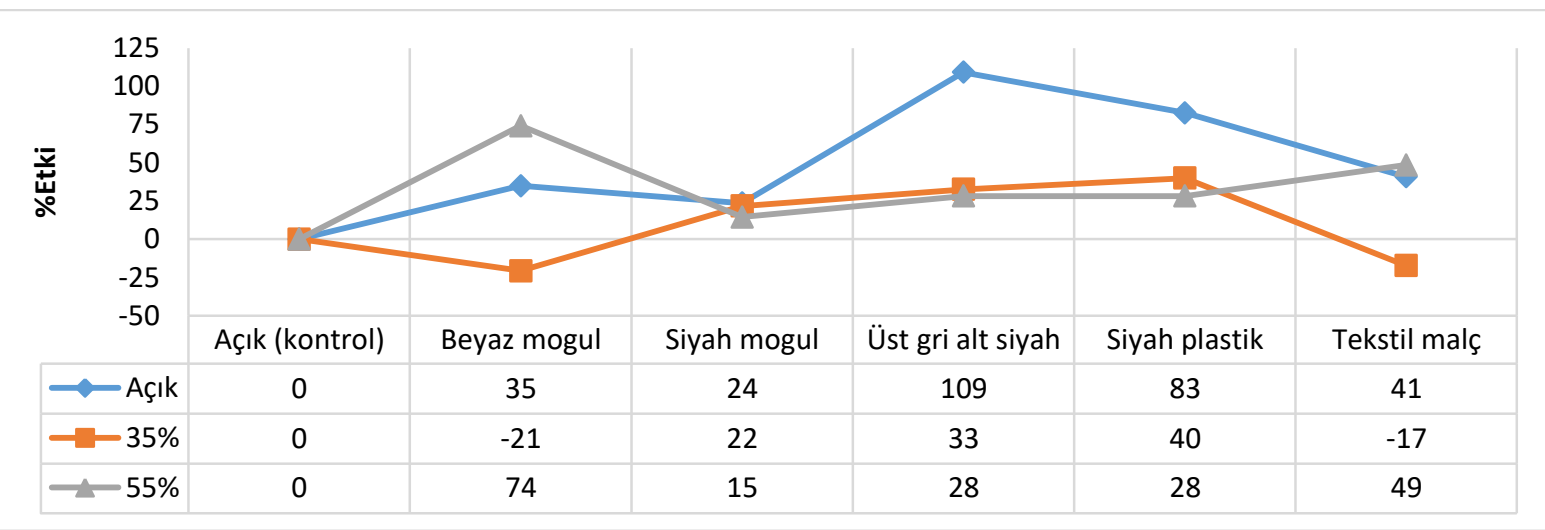

Şekil 9. Sürgün uzunluğunda yüzde etki

plastik malç materyalinde (\%109) meydana gelirken bunu açıkta siyah plastik (\%83) ve \%55 gölgede beyaz mogul takip etmiştir. En az etki ise \%55 gölge altında siyah mogul uygulamasından (\%15) elde edilmiştir.

Van Der Westhuizen (1980), bağ alanında yaptığı çalışmada siyah plastik malçın sürgün uzunluğunu olan etkilerini araştırmıştır. 1972-1975 yılları arası yapılan ölçümler sonucunda malç uygulaması yapılan asmalar malçsız uygulamalara göre her sene daha uzun sürgün uzunluğuna sahip olduğunu bildirmiştir.

Manisa yöresinde sıcaklık değerlerinin yüksek ve vegetasyon süresinin uzun olduğu düşünüldüğünde sürgün uzunluğunun \%35 ve \%55 gölge oranına sahip netler altında ve koyu renkli plastik malç altında yetiştiricilikte daha fazla olduğu söylenebilir.

SONUÇ

Çalışmada aşağıdaki sonuçlar elde edilmiştir.

- Toprak sıcaklığı, malç yüzey sıcaklığı ve aşı noktası sıcaklığı gölge oranı arttıkça azalmaktadır.

- Açıkta yetiştiricilikte örtü yüzeyi sıcaklığı daha fazla olmaktadır. Bu durum aşı noktasındaki sıcaklığı da etkileyebilmektedir.

- Siyah plastik malç uygulaması fidan kalite ve randımanı bakımından en yüksek değerlere sahip olmuştur.

- Malç uygulamalarında kullanılan mogul örtü materyali, gözenekli yapıda olması nedeniyle ısı ve ışığı geçirerek yabancı otların gelişimine olanak sağladığı gözlemlenmiştir.

- Plastik malç uygulamalarının diğer uygulamalara göre fidan kalite ve randımanını arttırmada daha üstün olduğu gözlemlenmiştir.

\section{Teşekkür}

Açık köklü asma fidanı üretiminde her türlü imkanı ve teknik bilgiyi bizimle paylaşan Nazım UZUN'a teşekkür ederiz.

\section{KAYNAKLAR}

Abak K, Pakyürek Y, Sarı N, Büyükalaca S (1991) Sera Kavun Yetiştiriciliğinde Malç ve Farklı Budama Yöntemlerinin Verim, Erkencilik ve Meyve İriliği Üzerine Etkileri. Çukurova Üniversitesi Ziraat Fakültesi Dergisi, 6: 3950.
Ağaoğlu YS (1977) Sofralık Üzüm Yetiştiriciliğinde Plastik Örtülerden Yararlanma İmkanları. Ankara Üniversitesi Ziraat Fakültesi, Yayın No: 660, Ankara.

Akman i, Ilgın C (1987) Tüplü Asma Fidanı Üretiminde Başarıyı Etkileyen Faktörler. Türkiye I. Fidancılık Sempozyumu, 26-28 Ekim, Tokat, 26-31.

Ağaoğlu Y, Çelik H, (1978) Bazı Amerikan Asma Anaçlarında Ethrel Uygulamaları ve Dikim Şekillerinin Köklenme Üzerine Etkileri. Ankara Üniversitesi Ziraat Fakültesi Yıllığı, Cilt:27: 574-587.

Aydin S (2012) Farklı Gölgeleme Düzeylerinin Aşılı Asma Fidanı Üretiminde Fidan Randımanı ve Kalitesi Üzerine Etkisi. Yüksek Lisans Tezi, Tokat Gaziosmanpaşa Üniversitesi, Tokat.

Cangi R (1996) Aşılı Asma Fidanı Üretimi ve Aşı Kaynaşmasının Anatomik, Histolojik ve Biyokimyasal Olarak İncelenmesi. Doktora Tezi, Yüzüncü Yıl Üniversitesi, Van.

Çelik H (1982) Kalecik Karası/ 41 B Aşı Kombinasyonu için Sera Koşullarına Yapılan Asma Fidanı Üretiminde Değişik Köklendirme Ortamları ve NAA Uygulamasının Etkileri. Doçentlik Tezi. Ankara.

Çelik H (2012) Türkiye Bağcılığı ve Asma Fidanı Üretimi-Dış Ticareti ile İlgili Stratejik bir Değerlendirme. TÜRKTOB (Türkiye Tohumcular Birliği) Dergisi 1: 10-16.

Çelik H (2017) Asma Fidanı Üretim Teknikleri, Önerilen Çeşitler ve Yenilikler. Fidancılık Sektör Analizi ve İnovasyon Çalıştayı, 20-22 Ekim 2017 Antalya.

Çelik H, Akgül V (1992) Aşılı Asma Fidanı Üretiminde Değişik Katlama Yöntemlerinin Aşıda Başarı Üzerine Etkileri. Türkiye I. Ulusal Bahçe Bitkileri Kongresi, 13-16 Ekim, İzmir, 455-458.

Çelik H, Odabaş F (1996) Farklı Örtü Materyallerinin Aşılı Çeliklerden Asma Fidanı Elde Etmede Başarı Üzerine Etkileri. Ondokuzmayıs Üniversitesi Ziraat Fakültesi Dergisi 3: 73-85.

Geboloğlu N (1998) Yüksek Plastik Tünellerde Hıyarın Verim ve Erkenciliği Üzerine Değişik Malç Materyalleri ve Ekim Zamanlarının Etkisi, II. Sebze Tarımı Sempozyumu, 26-28 Eylül, Tokat, 168-173.

Karipçin ZM (2004) Değişik Malç Tipleri, Sulama Aralık ve Düzeylerinin Plastik Serada Yetiştirilen Baş Salatanın 
(Lactuca sativa var. Capitata) Verim ve Bazı Kalite Özelliklerine Etkileri. Yüksek Lisans Tezi, Harran Üniversitesi, Şanlıurfa.

Keller M, Arnink KJ, Hrazdina G (1998) Interaction of Nitrogen Availability during Bloom and Light Intensity During Veraison. I. Effects on Grapevine Growth, Fruit Development, and Ripening. American Journal of Enology and Viticulture 49: 341-349.

Kesgin M (2011) Sofralık Amaçlı Sultani Çekirdeksiz Üzüm Yetiştiriciliğinde Gölgeleme-Örtü Materyali Uygulamalarının Hasadı Geciktirme ve Üzüm Kalitesine Etkisi. Yüksek Lisans Tezi, Tokat Gaziosmanpaşa Üniversitesi, Tokat

Kitiş YE (2002) Isparta İli Domates Ekiliş Alanlarındaki Yabancı Otların, Rastlama Sıklıklarının ve Yoğunluklarının Belirlenmesi ve Plastik Toprak Örtülerinin Yabancı Ot Kontrolü ve Domates Verimine Etkileri. Yüksek Lisans Tezi, Süleyman Demirel Üniversitesi, Isparta.

Kliewer M, Lider LAB, Schultz HB (1967) Influence of Artificial Shading of Vineyards on The Concentration of Sugar and Organic Acid in Grapes. American Journal of Enology and Viticulture 18:78-86.

Küçükyumuk C (2009) Aşılı Asma Fidanı Üretiminde Farklı Sulama Aralıkları ve Malç Uygulamalarının Fidan Randımanı ve Kalitesi Üzerine Etkileri. Doktora Tezi, Süleyman Demirel Üniversitesi, Isparta.

Libik A, Wojtaszek T (1973) The Effect of Mulching on The Behavior of Some Nutrient Compounds in The Soil. Acta Horticulture (ISHS) 29: 395-404.

Lopez-Pineiro A, Albarràn A, Nunes JM, Barreto C (2008) Short and Medium-Term Effects of Two-Phase Olive Mill Waste Application on Olive Grove Production and Soil Properties Under Semiarid Mediterranean Conditions. Bioresource Technology 99: 7982-7987.

Sağlam H, Yağcı A, Sağlam Öç (2005) Bazı Amerikan Asma Anaçlarında IBA Kullanımının Fidan Kalite ve
Randımanına Etkileri Üzerine Araştırmalar. Türkiye 6. Bağcılık Sempozyumu, 19-23 Eylül, Tekirdağ, 554-560

Sevgican A (1999) Örtü Altı Sebzeciliği. Ege Üniversitesi Ziraat Fakültesi, Yayın No: 528, İzmir.

Smart RE, Smith SM, Winchester RV (1988) Light Quality and Quantity Effects on Fruit Ripening for Cabernet Sauvignon. American Journal of Enology and Viticulture 39: 250-258.

Şen A, Yağcı A (2016) Tüplü Asma Fidanı Üretiminde Farklı Köklendirme Yerlerinin Fidan Randıman ve Kalitesi Üzerine Etkileri. Meyve Bilimi 3: 22-28.

Uzun T (2019) 1103 Paulsen Anacı Üzerine Aşılanan Bazı Sofralık Üzüm Çeşitlerinin Açık Köklü Fidan Randımanlarının Belirlenmesi. Harran Tarım ve Gıda Bilimleri Dergisi, 23(3): 287-294

Van Der Westhuizen VDJH (1980) The Effect of Black Plastic Mulch on Growth, Production and Root Development of Chenin Blanc Vines under Dryland Conditions. South African Journal of Enology and Viticulture 1: 16.

Yağcı A, Aydin S, Cangi R, Topçu N, Sucu S, Kılıç D, Akgül DS (2012) Determination of Effects on Grapevine Production of Different Shading Ratios. The XXXVrd World Congress of Vine and Wine 10th General Assembly of The O.I.V. 18-22 June, Izmir (Turkey).

Yağcı A, Aydin S (2015) Açık Köklü Asma Fidanı Üretiminde Farklı Gölgeleme Oranlarının Fidan Randıman ve Kalitesine Etkileri. Selçuk Tarım ve Gıda Bilimleri Dergisi A, 27: 146-153.

Yağcı A, Gökkaynak AG (2016) Sultani Çekirdeksiz Üzüm Çeşidinin Fidan Randımanı ve Kalitesi Üzerine Anaç ve Gölgeleme Oranının Etkisi. Ege Üniversitesi Ziraat Fakültesi Dergisi 53: 109-116.

Yazgan A, (1987) Fidancılık İşletmelerinde Cam ve Plastik Örtülerin Düzenlenmesi. Türkiye I. Fidancılık Sempozyumu, 26-28 Ekim, Tokat, 31-35 